\title{
Revisiting the US Food Retail Consolidation Wave: Regulation, Market Power and Spatial Outcomes
}

\begin{abstract}
This paper revisits Neil Wrigley's influential research that explored the corporate restructuring of the US food retail sector, which was characterised by a focus on the spatial implications of merger activity, market concentration and competition regulation. It assesses the importance of this scholarship in a contemporary context, tracking these competitive and regulatory trends from a decade ago to the present. This is of particular interest given the continued concentration of market power and related competitive shake-out; the innovative experimentation with new store formats; anti-trust rulings concerning market definition by the Federal Trade Commission (FTC); and the challenges faced by European entrants to the market.
\end{abstract}

Keywords: economic geography; retailing; regulation; divestiture, antitrust

JEL classifications: L81, D81, D92, F21

Paper prepared for special session in Honour of Professor Neil Wrigley at the AAG Annual Meeting, February 24-28, 2012, New York, NY and for submission to a special issue of Journal of Economic Geography

Revised following referees' comments. September 2012

THIS IS NOT THE PUBLISHED VERSION BUT THE ACCEPTED MANUSCRIPT AT THE PRE-PRODUCTION STAGE 


\section{INTRODUCTION}

Soon after Neil Wrigley's argument for a 'new' retail geography in the mid-1990s (Wrigley and Lowe, 1996), his work increasingly focused on the conceptualisation of corporate retail structures to partly explain the emerging spatial expression and configuration of store networks. While exhibiting a long standing research interest in UK food retailing (Wrigley, 1991), originating from an extensive background in store network planning and quantitative modelling (e.g. Dunn et al., 1983; Wrigley, 1988; Wrigley and Dunn, 1984), in the mid-1990s he was given the opportunity by the Leverhulme Trust to conduct research into what he predicted to be the forthcoming consolidation wave within US food retailing. My argument is that this series of publications spanning the late 1990 s and early 2000 s represented an important phase in Wrigley's career and within economic geography more widely. First, the research obviously represents a discrete multi-disciplinary explanatory contribution related to the landscape of US food retailing. Furthermore, in a research environment where scholarship is increasingly judged in terms of its 'impact' (Gray et al., 2009; Johnson, 2008), the research stream achieved traction across a range of disciplines including economic geography (Wrigley, 1999a; 1999b); retail management (Wrigley, 1998b; 2002b); agricultural economics (Wrigley, 2001a) and marketing (Wrigley, 2000a).

Second, and more significant for the discipline from an historic perspective, the project explores a number of themes that were at that time under-developed within economic geography-including the role that the regulatory state may have in channelling corporate strategy and subsequent spatial outcomes; how a firm's capital structure can influence merger and acquisition activity and patterns of regional and national business ownership; and finally, a number of outputs (Wrigley, 1997b; 1997c;1997d; 1997e; 2000a, 2000b) started to address the challenges associated with expanding a retail business beyond its home market. Such a theme of retail internationalisation has subsequently become a major research topic across the social sciences (see Journal of Economic Geography 2007 special issue on Global Retailing, Volume 7, No. 4) and one that promotes wide ranging interdisciplinary debate (Coe, 2004; Coe and Wrigley, 2009).

This paper is structured as follows: First, I discuss Wrigley's arguments relating to the emerging geography of US food retailing in the 1980s and 1990s that places its explanatory emphasis on a firm's capital structure, the role of national and state-level regulation, the scale-related power associated with retail capital concentration and the role of corporate strategy. Second, I reflect on the 
significance of Wrigley's thesis a decade on; analysing the developments within US food retail economic geography since 2002. Third, the paper briefly reviews the thematic contribution of the research and its implications for the development of economic geography more broadly.

\section{GEOGRAPHIES OF US FOOD RETAIL RESTRUCTURING IN A 1990s POST-LBO LANDSCAPE}

The mid-late 1990s saw the US food retail market in a period of remarkable change with a dramatic wave of consolidation sweeping through the industry, in turn transforming its corporate geography toward concentration levels more characteristic of European retail markets. In 1992, the top five food retailers accounted for $27 \%$ of food sales, yet by 2001 this had increased to $38 \%$ (see Table 1 ).

Table 1: The leading US food retailers 1992, 2001

\begin{tabular}{|cc|cc|}
\hline \multicolumn{2}{|c|}{1992} & \multicolumn{2}{c|}{2001} \\
\hline Company & $\begin{array}{c}\text { Market Share } \\
(\%)\end{array}$ & Company & $\begin{array}{c}\text { Market Share } \\
\text { (\%) }\end{array}$ \\
\hline Kroger & 7.7 & Kroger & 11.1 \\
\hline American Stores & 6.6 & Safeway & 7.5 \\
\hline Safeway & 5.3 & Albertsons & 7.2 \\
\hline A\&P & 3.7 & Walmart * & 6.3 \\
\hline Winn-Dixie & 3.6 & Ahold. & 5.8 \\
\hline
\end{tabular}

* Supermarket type sales only

Source: data obtained from Wrigley 1998b, p 139; Bank of America/Merrill Lynch (2011); Wrigley (2001a); US Census Bureau

The reasons for this significant change lay in a combination of factors including the evolving capital structure of the constituent firms, changing enforcement of competition and investment rules by the Federal Trade Commission (FTC) and the strategic investment regimes pursued by the retailers. Such conditions would alter a market structure that had been essentially regional and remarkably dispersed in ownership terms toward a concentration of capital which increasingly displayed similarities with the UK food retail market where the leading firms leveraged their scale and assumed a so-called 'channel captain' role in the supply chain (Hughes, 1999; Wrigley, 1997b).

\section{The role of capital structure restricting consolidation: The 1980s LBO wave}

Wrigley's research therefore tracks the developments across the industry in order to explain both the consolidation wave and its previous long-standing unconcentrated, regional market structure. In part responding to a call within the discipline to better conceptualise the nature and implications of the arbitrage economy and framing regulation as a social practice (Clark, 1992a; 1992b), Wrigley (1998b; 1999a; 1999b) identifies the period of financial re-engineering (leveraged acquisitions, buy-outs [LBOs] 
and recapitalisations) over the 1980s as a key factor that had held back industry consolidation that would otherwise have occurred - issues similarly debated within agricultural economics (Cotterill, 1991). LBOs and leveraged recapitalisations were considered a method of overcoming the 'corporate control failure' common in large firms ${ }^{1}$. Financial leverage was therefore seen as encouraging an organisational change that would offer the potential for improved shareholder returns and operating efficiency. Specifically, debt was thought to open the management of large public companies to monitoring and discipline from capital markets, and to force them to make harsh decisions, eliminate excess capacity, and direct cash flow to the most productive uses (Wrigley, 1999b, p 185).

Such financial re-engineering rested on the premise that many businesses sub-optimised their return for equity investors by over-conservative gearing. Hence, pressures created by the need to service high debt levels would concentrate management on cash flow to pay down the debt burden. Financial economists, most notably Michael Jensen (1986; 1989a), argued that traditional public companies channelled free cash flow in excess of that required to fund all positive net present value projects, causing conflicts of interest between managers and shareholders. In contrast, managers who acted in the interests of shareholders were viewed as returning this free cash flow to shareholders (Jensen, 1986), whilst managers in non-leveraged public companies were characterised as pursuing strategies of growth rather than enhancing shareholder value (Jensen, 1989a). Increased gearing was therefore seen as the way to eliminate this unproductive investment (Jensen, 1986; 1989a; 1989b). The pro-leverage school believed that the benefits for shareholders in harnessing free cash flow would be substantial in the form of a more efficient, shareholder-focused firm that would benefit from greater tax incentives (Jensen, 1986) and that these benefits would surpass any costs associated with financial distress (Opler and Titman, 1993).

The highly leveraged transactions were themselves realised through the relaxation of investment regulations that permitted the evolution of a new type of financial instrument - so-called 'junk'

\footnotetext{
${ }^{1}$ In definitional terms, the leveraged buy-out occurs when third party investors and/or managers of a firm offer to pay a premium over the prevailing market price of the firm and finance the exchange of corporate control by taking on a significant amount of debt (Wrigley, 1999a). Similarly, a leveraged recapitalisation occurs where a firm borrows in order to pay a large dividend to shareholders of at least 50 per cent of the former equity value of the firm (Chevalier, 1995). Similar efficiency generating arguments, as those espoused in LBOs, operate in the case of leverage recapitalisations, but there are some important differences between the two in terms of ownership structure. As Wrigley (1999a; 1999b) points out, LBOs are characterised by larger increases in managerial ownership and commonly involve active third-party investment specialists (e.g. KKR) who gain control of the firm and often take the firm private for a time. It is during this period that the firm will be rationalised, where important changes are imposed on the corporate governance of the corporation.
} 
bonds. These were high yield, non-investment-grade securities, pioneered by the investment bank, Drexel Burnham Lambert, reflecting more risk borne by shareholders than in a typical public company (Jensen, 1989a). In effect, this capital market innovation had the effect of eliminating mere size as a takeover deterrent (Jensen, 1988) - as Wrigley (1999a) suggests, 'the development of this market allowed non-investment-grade firms, previously shut out of the corporate bond market, access to capital (particularly vital fixed-rate funding) without the risks associated with costly and dilutive equity offerings' ( $p$ 291). Firms such as Kohlberg Kravis Roberts (KKR) formed, specialising as third party organisations to instigate the LBOs, which would capitalise on the increased value generated from the efficiency gains after a number of years of ownership (Baker and Smith, 1998).

In common with economists of the period (Denis, 1994; 1995), Wrigley (2001a) argues that the US food retailers were especially suited to these financial innovations given their stable cash flows, combined with their need to increase efficiency and productivity. Transactions varied in size and included the \$4-5 billion Safeway and Kroger LBO/recapitalisations; the \$2.5billion leveraged acquisition of Lucky by American Stores and the \$1-2 billion LBOs of Stop \& Shop and Supermarkets General (Wrigley, 1999b). Between 1985-1988, 19 of the 50 largest firms in the sector $-25 \%$ of the market in sales terms - reorganised via various forms of LBO or leveraged recapitalisation (Chevalier, 1995). Debt to capitalisation ratios in a sample of 34 firms in the sector increased from $46 \%$ to $71 \%$ between 1985 and 1989 (Wrigley, 1999a).

The spatial implications for the economic geography of the US food retail market due to these debt burdens were threefold. First, a geography of divestiture occurred as chains and stores deemed peripheral or expendable were sold to finance the debt burden. Second, linked with this issue, there was a spatial rationalisation of production and capacity. Third, the remaining retail chains and divisions were placed under greater pressure to operate efficiently. However, inherent within these trends, Wrigley (1999a) identifies slightly different strategic responses to the debt pressures which had their own distinct spatial implications - something also evident in economists' comparison of the two transactions (e.g. Denis, 1994). While Safeway's immediate response was a concerted disposal of assets - \$2.4 billion (1,000 stores) in the two years following its 1986 LBO; in contrast Kroger sold only $\$ 351$ million of assets over a similar period and appeared therefore not to be in a position to commit as much capital investment later in modernising its remaining store estate (Wrigley, 1999b). 
In general, the debt encumbered nature of the retailers and the subsequent divestiture of assets, led to a 'geography of avoidance' with 'a surprisingly low degree of intra-market competition between major firms' (Wrigley, 1999b, p. 197). In essence, forcing retailers to pursue a 'core focus' strategy as discussed by Clark and Wrigley (1997), operators concentrated on those markets where they enjoyed strong positions and often market leadership, eschewing those catchments and regions where competition would prove more fierce and less profitable in the short-medium term. Such divestiture also provided opportunities for predation by well capitalised competitors that could realise strong returns with relatively limited investment. For example, in the case of Dutch food retailer, Ahold, that was aggressively expanding its US store portfolio, Wrigley (1998b, p 132) summarises its strategic approach as one in which it would 'acquire underperforming, leveraged and/or financially distressed US chains, often in smaller markets and, via judicious refinancing and relatively small scale investment...achieve rapid payback on its investment'.

\section{The 1990s deleveraging, consolidation and centralisation imperative}

The capital constrained nature of the US food retail market following the financial re-engineering of the 1980s essentially prevented wide-ranging merger and acquisition activity and therefore preserved an operationally decentralised and typically regional market structure. However, the gradual deleveraging of the previously financially stressed operators through the 1990s partly provided conditions whereby capital expenditure could once again increase and ambitious centralisation/selfconsolidation initiatives could confront 'the diseconomies of scale that had dogged their fragmented divisional level operating structures of the 1980s' (Wrigley, 2001a, p 498 - see Figure 1). Such developments included centralised own label programmes; the co-ordination and updating of technologies; the consolidation of administrative support functions; the introduction of integrated logistics practices and the sharing of 'best practices' between divisions that were often historically operated largely independently. For example, the Dutch retailer, Ahold, that had previously pursued a "hands-off" management style - operating US divisions as little more than holding companies from 1995 changed its strategy with an initiative labelled 'Project Compete' and commenced the back office operational integration of its US fascias (Wrigley, 1997a). Such trends had parallels elsewhere within the US retail market, most notably in the US department store sector where there had been high profile Chapter 11 bankruptcy filings following failed leveraged restructurings, involving Macy's, Allied and Federated Department Stores, which led to a similar push toward centralised, consolidated and more efficient operations (Wood, 2001; 2002a; 2002b). 


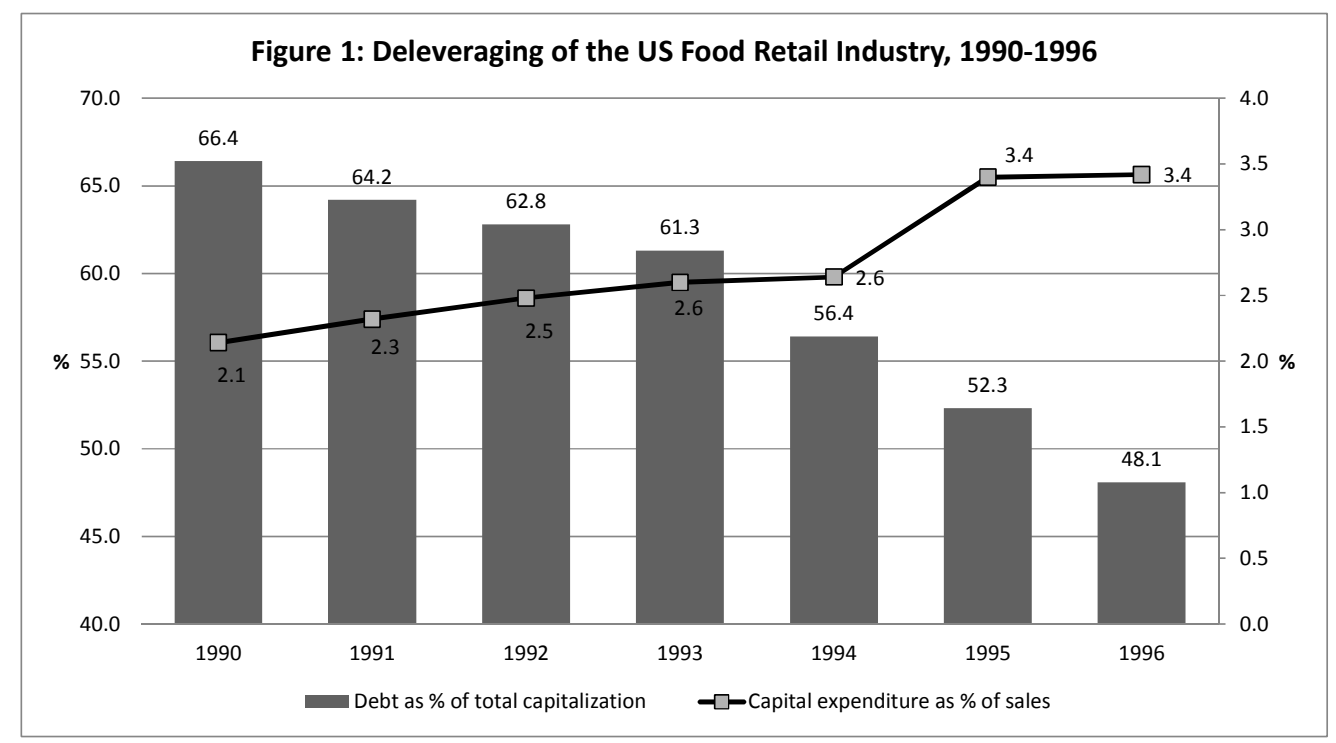

Source: adapted from Wrigley, 2001a, p 498

In addition, scale-related advantages and the centralisation of practices out of view of the customer were also met with increasingly larger retail formats, notably the $150,000 \mathrm{sq} f \mathrm{ft}+$ supercenters. These formats were pioneered by Meijer in Michigan in 1962 and also Fred Meyer in the Pacific Northwest but expanded aggressively by Walmart. Such formats sell food that ensures regular customer footfall to the store along with a strong general merchandise offer that had previously been the focus of the conventional discount store.

The benefits associated with scale became increasingly apparent and as retailers' balance sheets recovered following the LBO period and merger and acquisition activity increased within the sector to remarkable levels. Such wide ranging changes are summarised by US regional geography in Table 2 . Chief amongst them are two mergers in 1998 when Kroger, at the time the largest US grocery retailer, merged with Fred Meyer to form a multi-regional supermarket operator with 2,200 grocery stores across 31 states, while Albertsons, at the time the fourth largest food retailer, merged with American Stores resulting in the company operating 1,690 stores in 38 states. 
Table 2: Selected Mid-late 1990s US Food Retail Consolidations by Regional Geography

\begin{tabular}{|c|c|c|}
\hline Acquiring and acquired retailer & $\begin{array}{c}\text { Grocery stores acquired } \\
\text { (Number) }\end{array}$ & Sales of acquired stores (\$m) \\
\hline \multicolumn{3}{|l|}{ Pacific Region: } \\
\hline Safeway - Vons, 1997 & 325 & 5,400 \\
\hline Yucaipa - Fred Meyer, 1997 & 101 & 3,124 \\
\hline Quality Foods Centers - Hughes, 1997 & 57 & 1,250 \\
\hline Yucaipa - Smiths Food \& Drug, 1997 & 150 & 3,000 \\
\hline Yucaipa - Quality Foods Centers, 1997 & 203 & 1,200 \\
\hline Albertsons - Lucky (American Stores), 1998 & 448 & 8,295 \\
\hline \multicolumn{3}{|l|}{ Midwest Region: } \\
\hline Giant Eagle - Riser Foods, 1997 & 56 & $4,000 * *$ \\
\hline Lund's - Byerly's, 1997 & 11 & 65 \\
\hline Albertsons - Jewel/Osco (American Stores), 1998 & 171 & 3,166 \\
\hline \multicolumn{3}{|l|}{ Northeast Region: } \\
\hline Ahold - Stop \& Shop, 1996 & 189 & 4,400 \\
\hline Ahold - Giant Food, Inc., 1998 & 176 & 4,200 \\
\hline Albertsons - Acme (American Stores), 1998* & 183 & 3,388 \\
\hline Food Lion - Hannaford, 1999 & 150 & 3,400 \\
\hline \multicolumn{3}{|l|}{ Southeast Region: } \\
\hline Food Lion - Kash \& Karry (Florida), 1997 & 100 & 1,000 \\
\hline Jitney Jungle - Delchamps, 1997 & 118 & 1,300 \\
\hline Kohlberg \& Co. - Schwegmann's, 1997 & 26 & 115 \\
\hline \multicolumn{3}{|l|}{ Inter-regional: } \\
\hline Safeway - Dominicks, 1998 & 112 & 2,300 \\
\hline Kroger - Yucaipa/Fred Meyer, 1999 & 800 & 15,000 \\
\hline Safeway - Randalls, 1999 & 116 & 2,500 \\
\hline
\end{tabular}

*Total sales of American Stores (Lucky, Jewel/Osco, and Acme) was \$19.9 billion in 1998. Sales by region exclude sales of 773 pharmacy/drugstores.

** Sales include wholesale sales to 586 independent grocery retailers.

Source: Kaufman (2000)

The role of the FTC in influencing spatial outcomes: fix-it-first approaches and late 1990s regulatory

\section{tightening}

Wrigley's explanation for the structure of the US retail food market owes a great deal to the changing regulatory interpretation of the FTC and the implications that this subsequently had for the retail landscape. In particular, the predominantly laissez-faire philosophical approach of the Reagan administration of the 1980s is seen as a significant influence in the relaxation of anti-trust actions especially in terms of being far less likely to implement the provisions of Section 7 of the Clayton Act that would otherwise have restricted many of the horizontal and market extension acquisitions (Wrigley, 1992). Interestingly, a gradually stricter interpretation emerged from the FTC toward the end of the Reagan Administration with greater sensitivity paid to anti-competitive issues. Of particular importance is the landmark challenge to the merger of American Stores with Lucky Stores 
Inc. in 1990 where the State Attorneys General of California's challenge was carried successfully to the Supreme Court and led to American divesting its entire 145 store Alpha Beta chain (Wrigley, 1997a).

Not only therefore did the geography of merger and acquisition have to be considered in terms of retail strategy (namely the "practical workability" of the transaction such as potential store overlaps and consequent sales cannibalisation; implications for market position, logistical systems and synergistic potential) but also in terms of likely competition issues and FTC/state level response (the degree of horizontal market overlap and the implied divestment implications). Given the likely prohibitive regulatory action, Wrigley (1999a) traces the 'dance of courtship' as the range of potential partners for individual regional chains progressively reduced as the consolidation process advanced, along with the implied market value of such chains.

The implications of competition regulation therefore became a key consideration for retail firms and were increasingly factored into the proposed geography of merger and acquisition activity by the acquirer at an early stage via what became known as a "fix-it-first" approach. As Wrigley (2001b, p 191) explains, the FTC tacitly agreed 'not to oppose mergers and acquisitions where the acquiring firm committed itself in advance (under the spirit of the Celler-Kefauver Act) to divest itself of all clear horizontal market overlaps that might be deemed to be uncompetitive at the local level' (see also Wood, 2001). However, state level Attorneys General often sought to impose greater levels of divestiture, with the American Stores merger providing a precedent that was subsequently replicated in numerous cases (Wrigley, 1997a). These divestitures - whether part of "fix-it-first" concessions or subsequently enforced due to FTC/Attorneys General actions - on occasion provided unexpected market position to competitors. For example, the divestitures associated with Ahold's acquisition of Stop \& Shop in New England provided a major boost to UK retailer, Sainsbury's Shaw's chain as it was able to acquire 13 stores (Wrigley, 1997a).

Towards the end of the 1990s, the fix-it-first policy of effectively leaving it to retailers to resolve any competition issues relating to the geography of their consolidations became seriously questioned. In particular, there was concern that acquiring retailers tended to 'cherry-pick' divestitures, often sacrificing underperforming units and leaving their stores that enjoyed stronger market position effectively untouched by competition policy (Wrigley, 2001b). A particular concern for more effective 'crown jewel divestitures' became widespread following pronouncements by the FTC (e.g. Baer, 1996). 
As the former FTC Chairman reflected, a tightened level of enforcement involved more significant divestiture and even divestiture outside of the regions of horizontal market overlap:

In cases where there was some uncertainty about the saleability of certain asset packages, the Commission began to demand "crown jewels" - larger asset packages to be sold by a trustee in cases where the smaller asset package attracted no acceptable purchasers. In other cases, the FTC insisted that the merging parties divest a package that included more assets than just those in the markets where competitive problems were found. In retail markets, the Commission demanded that the parties divest all of the stores of either the acquiring or the acquired company; "mix and match" settlements involving the divestiture of some assets from each of the merging parties were no longer accepted (Baer and Redcay, 2001, p 1705).

Indeed, a study of the effectiveness of historic divestitures by the FTC (1999) reinforced the view that stricter enforcement would retain strong competition in the marketplace. The report noted that although divestitures generally created viable competitors in the market of concern, divesting companies 'tend to look for marginally acceptable buyers and may engage in strategic conduct to impede the success of the buyer' who often lacks 'sufficient information to prevent mistakes in the course of their acquisitions' (FTC, 1999, p 8). It also recommended the logical conclusion that divestiture of ongoing businesses was more likely to result in a viable operation than divestiture of a more narrowly defined package of assets.

Wrigley (2001b) notes this stricter enforcement clearly feeding through to decision-making by late 1999 when the FTC required a much larger number of divestments in the merger of Albertsons and American Stores than had been anticipated by the organisations. In addition - and more significantly - the FTC's focus on effective divestiture led to them insisting on more "up front buyers" in consent decrees $^{2}$. Such a policy shift in regulatory enforcement led to the collapse of the proposed Ahold acquisition of Pathmark at the end of 1999. Despite respondents agreeing to sell-off stores in catchments where there was overlap between the two firms to retain the concentration ratio, this was deemed insufficient. Wrigley (2001b), in common with widespread legal interpretation (Balto, 2001; Baer and Redcay, 2001), argues that this represented a landmark decision that would influence the economic geography of retail expansion as numerical parity was no longer the key, but instead the momentum and likely success of the divested stores were factored into the decision-making process. Such a perspective is supported by the former Director of the FTC, William Baer, who acknowledged in 2001 that:

\footnotetext{
${ }^{2}$ By 1999 something that was insisted upon in approximately $60 \%$ of divestitures (Pitofsky, 2000)
} 
FTC staff reportedly refused to approve because of concern that the buyer - unlike the current owner - was not part of a much larger and well funded parent organization. Specifically, the concern was that the larger organization might not be able to provide the level of support and to furnish access to customer and supplier relationships needed to maintain the same level of rivalry (Baer and Redcay, 2001, p 1701).

Indeed, there followed a number of further regulatory interventions by the FTC, leading Wrigley (2001b, p 193) to argue that the shifts in regulatory interpretation and enforcement led to a stifling of merger activity for the foreseeable future as:

...in-market acquisition, which had provided the leading firms in the US industry with the most secure route to the extraction of the synergistic cost-saving benefits that had powered the consolidation wave, were effectively disallowed by the FTC's new stance on inadequate divestiture remedies and on the momentum of the acquiring firm.

\section{THE EMERGING RETAIL GEOGRAPHY OF US FOOD RETAILING, 2002-2011}

Many of the trends that Wrigley identified within the US food retail market through the late 1990s have intensified during the 2000s. That is to say, there has been an increasing concentration of "big" capital primarily through the market dominance of general merchandise-turned-food retailer, Walmart. The efficient business model and continued rapid spatial expansion of the operator has had the competitive effect of demanding scale and sourcing efficiencies of food retailers and led to further competitive shake-out across the sector. As such, there has been an increasing squeeze on those smaller operators lacking scale-related efficiencies or those that do not occupy a differentiated niche in the market. These pressures have affected both large operators with extensive geographic coverage but also regional players and often led them to reorganise via Chapter 11 bankruptcy protection or to be vulnerable to predation by acquirers that themselves enjoy strong balance sheets and a distinctive and sustainable position in the market. As the Financial Times summarised at the end of 2011, the competition for the "food dollar" became considerable:

The US supermarket sector is highly fragmented with only a few groups able to boast a broad national presence. Competition for customers is intensifying and profit margins are falling as non-grocers such as dollar stores, drug stores and mass-market discounters improve their range of groceries in an attempt to attract shoppers away from supermarkets (Jopson, 2011). 


\section{The Walmart Challenge: Scale Requirements, the Spectre of Chapter 11 and Divestment}

The nature of Walmart's expansion is at the heart of understanding the pressure within a post-2000 US food retail market. As acknowledged earlier, the previous round of industry consolidation was driven by market conditions, the deleveraging of the main players and the seemingly available synergistic benefits accessible through operational centralisation, as much as by an explicit competitive pressure from Walmart. As Wrigley argued a decade ago:

That shift [to a more centralised]... business model helped change the economics of acquisition and merger in the industry during the late 1990s - reinforcing the increasing attractions in what had become a low inflation environment of the relatively secure earnings growth that could be derived from the synergistic cost savings associated with mergers and acquisitions. And it was that...rather than any direct defensive response to the incursion of Walmart supercentres into the market of the major food retailers, which was the link between Walmart's entry into the industry and the consolidation activities of those leading firms (Wrigley, 2002a, p 73-4).

However, the competitive conditions ramped up markedly as Wrigley's study left off. Figure 2 charts the growth in Walmart's store portfolio from 1989 to 2011. When Wrigley was writing in 2002, the development of Walmart supercenters - the large store format aligning food with a wide ranging general merchandise offer - only equated to just over 1,000 stores. At the time of writing (January 2012), this is approaching 3,000. In addition, the retailer has experimented with smaller store formats including Neighborhood Market (first opened in 1998, consisting of a c.40,000 sq ft supermarket and adjoined pharmacy drive-through) and Express convenience food stores (first opened in 2011 at $10,000-15,000 \mathrm{sq} f t)$. Alongside continued large format expansion, growth is increasingly channelled to these new smaller formats as they cater to changing consumer lifestyles but also penetrate urban catchments where the supercenter format may not viable for a range of location planning and political reasons. In October 2011, the retailer confirmed that it was increasing its expansion of smaller formats by up to four times, based on the previous fiscal year expansion (IGD, 2011). Such spatial proliferation has affected all established food operators. For example, by 2005, two thirds of Kroger's stores were situated within 20 miles of a Walmart supercenter which offered a keen Every Day Low Priced (EDLP) general merchandise and food offer (Birchall, 2005). Furthermore, by increasing its chain of smaller stores, Walmart directly competes with traditional convenience stores but also drug stores such as Walgreens and CVS that have developed their own food offers. 


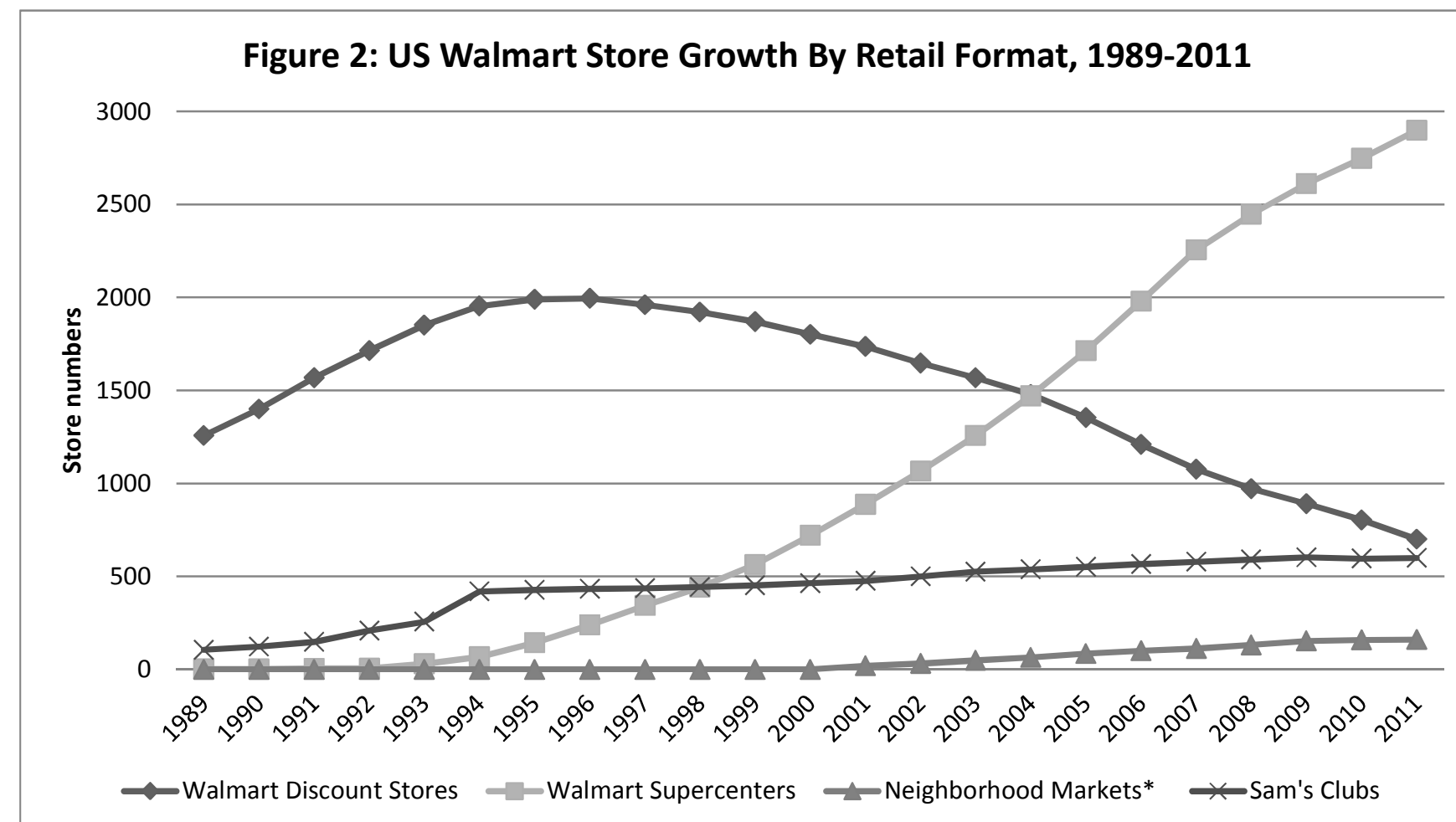

* inc. Marketside and Supermercado formats

Source: Walmart 10k reports 1989-2011

Figure 3 charts the growth of the leading food retailers over the period 2006-2010. Again the growth of Walmart is particularly in evidence in consistently outstripping its competitors.

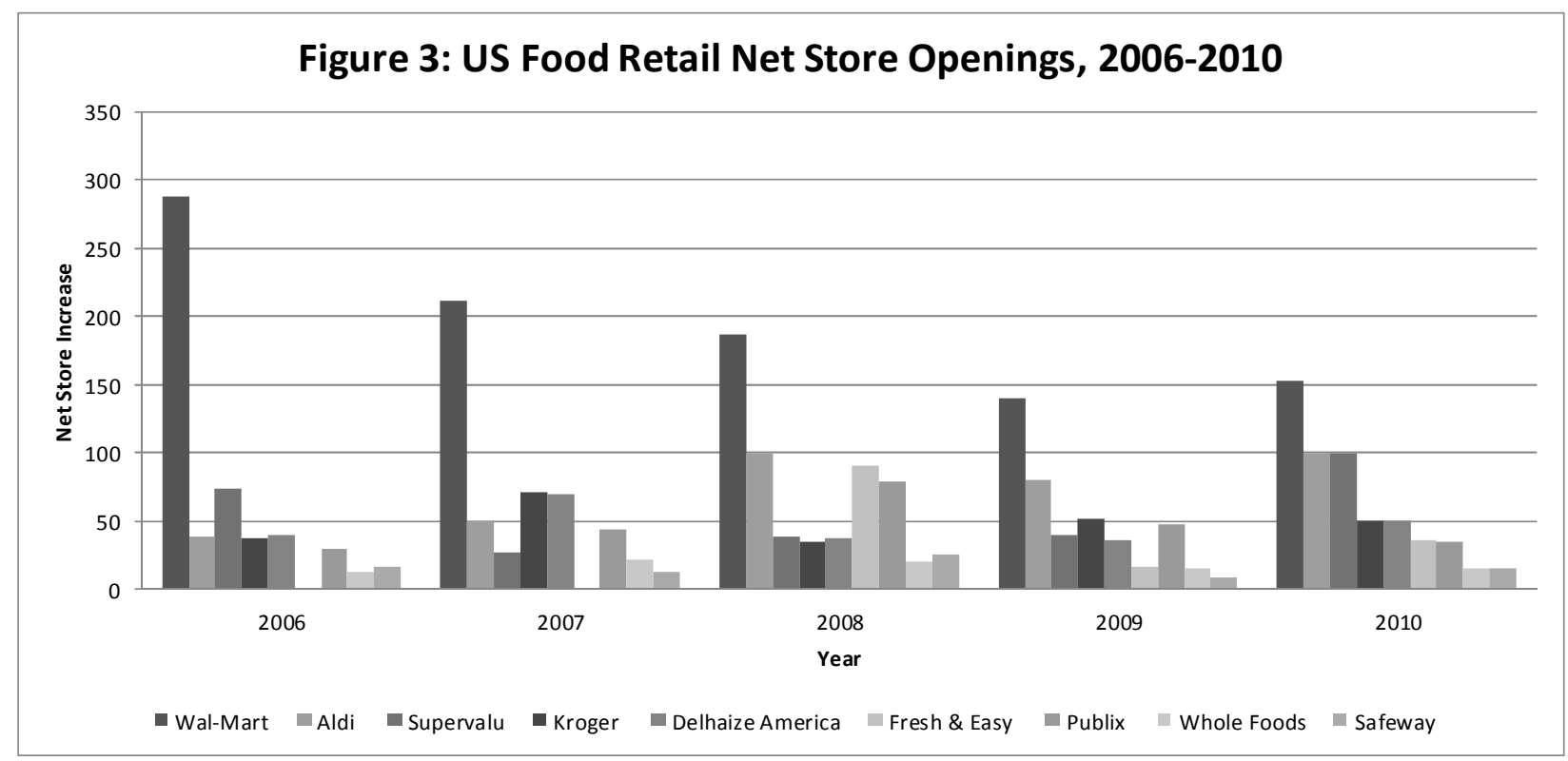

NA: Wal- Mart includes only formats containing food (ie. Supercenter; Neighbourhood). Figures include conversions to supercenter format from discount format.

Source: Company reports/Chain Store Age research 
While Walmart has traditionally been dominant in "small town America" and often resisted in its advance into large urban environments - not least due to its perceived effects on communities, businesses, wider social capital as well as its hostility to unionisation (Halebsky, 2004; Irwin and Clark, 2006; Goetz and Rupasingha, 2006; Paruchuri et al., 2009; cf. Carden et al., 2009) - recent spatial analysis suggests that it already has a No. 1 market share in six metropolitan markets with populations of 1 million or more and a second place position in a further six urban markets (see Table 3 and 4). Econometric analysis confirms that the most contentious of Walmart's store formats, the supercenter, is increasing market concentration across the country (Martens, 2008). Clearly such advance is aided by a retail real estate market that has high levels of availability and therefore relative low cost partly due to historically high levels of retail development but also increasingly down to the economic downturn that has seen numerous retailers failing or at the very least "right-sizing" their store portfolios for the new competitive conditions - something that contrasts with the situation in the spatially constrained UK where strategic food store development sites remain extremely valuable and sought after (cf. Wood and Reynolds, 2011, 2012).

Table 3: Walmart's Largest No. 1 Markets, 2010

(No. 1 share; 1-million-plus population)

\begin{tabular}{|llll|}
\hline Market & Population & Walmart share & No. of stores \\
\hline Dallas/Fort Worth & $6.49 \mathrm{M}$ & $27.3 \%$ & 93 \\
\hline Kansas City, Mo. & $2.03 \mathrm{M}$ & $23.8 \%$ & 26 \\
\hline Las Vegas & $1.96 \mathrm{M}$ & $21.7 \%$ & 27 \\
\hline Oklahoma City & $1.22 \mathrm{M}$ & $40.4 \%$ & 30 \\
\hline Birmingham, Ala. & $1.16 \mathrm{M}$ & $42.7 \%$ & 27 \\
\hline New Orleans & $1.07 \mathrm{M}$ & $33.4 \%$ & 14 \\
\hline
\end{tabular}

NB. All data for Walmart include all Walmart formats except Sam's Club

Source: Supermarket News (2011b) using data from Metro Market Studies 2010 Grocery Distribution Analysis and Guide

Table 4: Walmart's Largest No. 2 Markets, 2010

(No. 2 share; 1-million-plus population)

\begin{tabular}{|c|c|c|c|}
\hline Market & Population & Walmart share & No. 1 chain (share) \\
\hline Houston & $6.05 \mathrm{M}$ & $21.6 \%$ & Kroger $(22 \%)$ \\
\hline Phoenix & $4.43 \mathrm{M}$ & $18.1 \%$ & Fry's (26.7\%) \\
\hline St. Louis & $2.86 \mathrm{M}$ & $18.6 \%$ & Schnucks (28\%) \\
\hline Tampa/St. Petersburg, Fla. & $2.79 \mathrm{M}$ & $14.8 \%$ & Publix (43.9\%) \\
\hline Pittsburgh & $2.34 \mathrm{M}$ & $15.6 \%$ & Giant Eagle (36.1\%) \\
\hline Cincinnati & $2.14 \mathrm{M}$ & $19.3 \%$ & Kroger (41.2\%) \\
\hline Orlando, Fla. & $2.13 \mathrm{M}$ & $17.9 \%$ & Publix (28.4\%) \\
\hline San Antonio & $2.12 \mathrm{M}$ & $23.9 \%$ & H-E-B (53\%) \\
\hline Columbus, Ohio & $1.78 \mathrm{M}$ & $17.6 \%$ & Kroger (37.3\%) \\
\hline Indianapolis & $1.76 \mathrm{M}$ & $21.9 \%$ & Kroger (25\%) \\
\hline
\end{tabular}

NB. All data for Walmart include all Walmart formats except Sam's Club

Source: Supermarket News (2011b) using data from Metro Market Studies 2010 Grocery Distribution Analysis and Guide 
In addition, other store formats have entered the food retail market to varying degrees which has deepened the pressure on conventional supermarket operators. Discount store retailers such as Target, as well as the so-called "dollar stores" (such as Dollar General and Family Dollar) have flexed their product ranges, while drug stores (such as CVS, Walgreens and Rite Aid), which offer convenient and accessible locations for customers, have ramped up their food offerings. This has led to a decline in the share of food sales that "traditional" food retailers account for: from 76\% in 1999 to $67 \%$ in 2009. In contrast, the share that warehouse clubs/supercenters generate has increased from less than $6 \%$ in 1999 , to over $18 \%$ only a decade later (see Figure 4). Traditional convenience stores have also continued to expand their store networks to over 148,000 by 2012 - an increase of $12 \%$ in a decade and the equivalent of one store per every 2,100 people (NACS, 2012). Although many lacking market power (though the 7-Eleven chain is a notable exception), with $63 \%$ of the industry made up of single store operations, these businesses have enhanced their product offer to increasingly include food-to-go food services aligned with accessible locations and long opening hours.

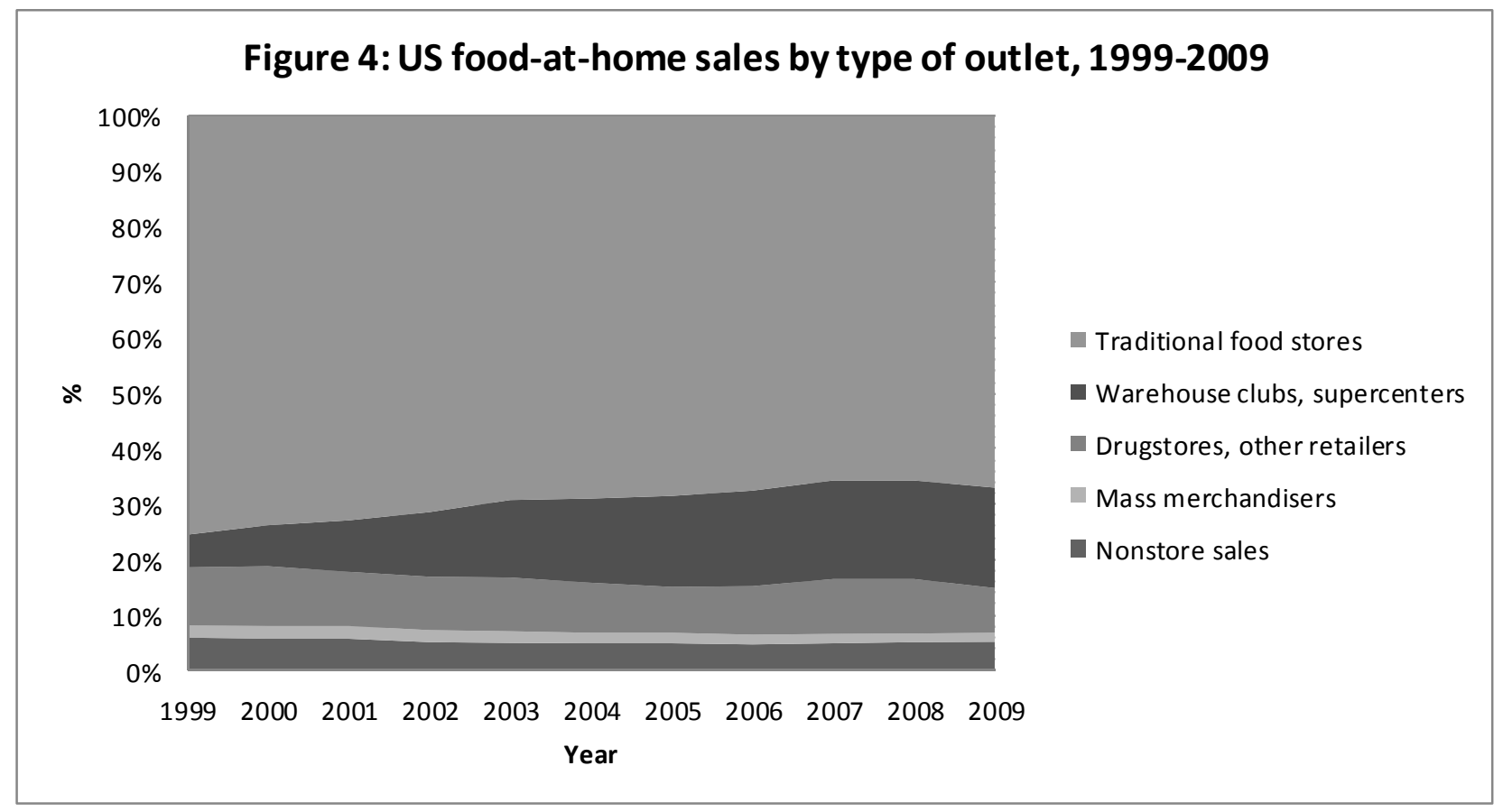

Source: USDA, ERS, Food Expenditures Table

Amid this environment of intense competition and the search for efficiencies and market differentiation, competitive fall-out has been common. The most notable casualty was Albertsons, which had previously been the third largest US food retailer. In 2005 the retailer announced that it was effectively seeking a "white knight" or friendly investor only 7 years after effectively doubling in 
size with the 1998 acquisition of American Stores for $\$ 11.7 \mathrm{bn}^{3}$ and only one year since acquiring Shaw's and Star Markets from UK food retailer Sainsbury's for $\$ 2.48$ billion. It was eventually acquired by a consortium of retailers and financial backers for $\$ 17.4 \mathrm{bn}$, chief amongst them Supervalu, the food retailer and wholesaler, which took possession of 1,126 of Albertsons' best-performing supermarkets across the US, including the Shaw's, Acme and Jewel names for $\$ 6.3 \mathrm{bn}$ in cash and shares and in the process acquiring $\$ 6.1$ bn of Albertsons' debt (Birchall, 2006) ${ }^{4}$. Meanwhile CVS acquired Albertsons' 700 drug stores. Despite the scale of the transaction, it was configured in such a way that no significant horizontal market overlap occurred and therefore the FTC did not require any divestiture.

Other operators similarly "caught in the middle" included Jacksonville-based Winn-Dixie Stores which filed for Chapter 11 bankruptcy protection in 2005 and at that time operated 920 stores (Grant, 2005) - when it emerged from Chapter 11 in November 2006, this was reduced to 522 stores such was the extent of the closure and divestiture undertaken (Winn-Dixie, 2006). In December 2011, it was announced that Winn-Dixie Stores would be taken private for $\$ 560 \mathrm{~m}$ cash by former Ahold-owned BiLo which was owned by private equity firm, Lone Star. Bi-Lo had itself only just emerged from a 2009 Chapter 11 bankruptcy protection (Jopson, 2011). Similarly, Bruno's, the other regional chain that had been divested to Lone Star by Ahold in 2005, entered Chapter 11 in February 2009. Finally, A\&P (The Great Atlantic \& Pacific Tea Co) - a retailer that has an illustrious history having aggressively expanded in the 1920s and 1930s (Tedlow, 1996) - entered Chapter 11 bankruptcy protection in December 2010, only emerging in March 2012 as a private company, operating 320 stores across six states, roughly only $2 \%$ of the more than 15,000 stores it had once traded (Reuters, 2012).

Meanwhile the performance of Dutch food operator, Ahold has stagnated within the US, partly due to the shockwaves emanating from a 2003 financial scandal relating to significant accounting irregularities (Wrigley and Currah, 2003; Clark et al., 2006). While some of these problems stemmed from the retailer's Argentinian business (Wrigley and Currah, 2003), in the US, the retailer was forced to restate more than $\$ 800$ million in earnings from its US Foodservice operation after executives had inflated promotional rebates from suppliers - something that led the retailer to pay $\$ 1.1$ billion to the Securities and Exchange Commission (SEC) to resolve shareholder lawsuits (Tse and Williams, 2007).

\footnotetext{
${ }^{3}$ The same year its rival Kroger had also reinforced its position with the $\$ 13.5 \mathrm{bn}$ acquisition of Fred Meyer.

${ }^{4}$ Somewhat later, in 2008, Florida-based regional food supermarket chain, Publix, acquired 49 Albertsons stores from Albertsons LLC, a private company owned by Cerberus Capital Management that had acquired 661 stores in the 2006 sale of Albertsons.
} 
Subsequently the US Foodservice division was divested to private equity groups Clayton Dubilier \& Rice and Kohlberg Kravis Roberts for $\$ 7.1 \mathrm{bn}$, including debt in 2007 . This led to a range of further divestitures of non-core assets to reduce debt and an overhauling of its remaining store estate to regain an investment grade credit rating. As Ahold acknowledged in its 2006 Annual Report, following a strategic review, it had 'decided to divest retail businesses that would require a significant level of investment and management attention. The Company will now focus on accelerating improvements across its remaining businesses' (Ahold, 2006, p 7).

Further US divestitures followed as the retailer focused on its core geographical areas with its Stop \& Shop and Giant Food Stores fascias and exited the south eastern region of the US where the spectre of the world's largest retailer loomed large. As the Financial Times put it, 'profitability has suffered due to fierce competition from discount retailers including Walmart' (Smith, 2004). In January 2005, Ahold sold two of its struggling regional food retail chains to private equity group, Lone Star, for \$660m: Birmingham Alabama-based, Bruno's which operated 168 stores in Alabama, Florida and Georgia, and also South Carolina headquartered Bi-Lo, which operated 287 stores across South Carolina, North Carolina, Georgia and Tennessee (Birmingham Business Journal, 2004; Shellock and Yuk, 2004). In addition, despite being the market leader in New York and Pennsylvania, the retailer divested its 76 Tops Markets stores in 2007 for $\$ 310$ million (Morgan Stanley, 2007), acknowledging that 'the divestment will allow the Company to focus resources on its remaining retail growth businesses' (Ahold, 2006, p 7).

\section{Market concentration and market power}

While a further increase in market concentration over the past decade may initially be seen as unremarkable given similar tendencies across other developed retail markets (Swinnen and Vandeplas, 2010), the scale and rapid nature of the change in concentration levels is worthy of exploration. The top 5 food retailers accounted for $27 \%$ of food sales in 1992 , to $38 \%$ of sales in 2001 , to $60 \%$ of sales in 2009 (see Figure 5; Table 5) 5 .

\footnotetext{
${ }^{5}$ As the US food retail market centralises, so Schwartz and Lyson (2007) argues so there emerges a concentration of power in the agriculture, food and nutrition system where there are linkages - both direct and indirect - in terms of presence on the main boards of retailers. The research, however, falls short of arguing that these interlocking directorates are a form of power that is harnessed in any meaningful way to the detriment of consumers or producers.
} 
Table 5: Market shares of the top 5 largest US food retailers 1992, 2001, 2009

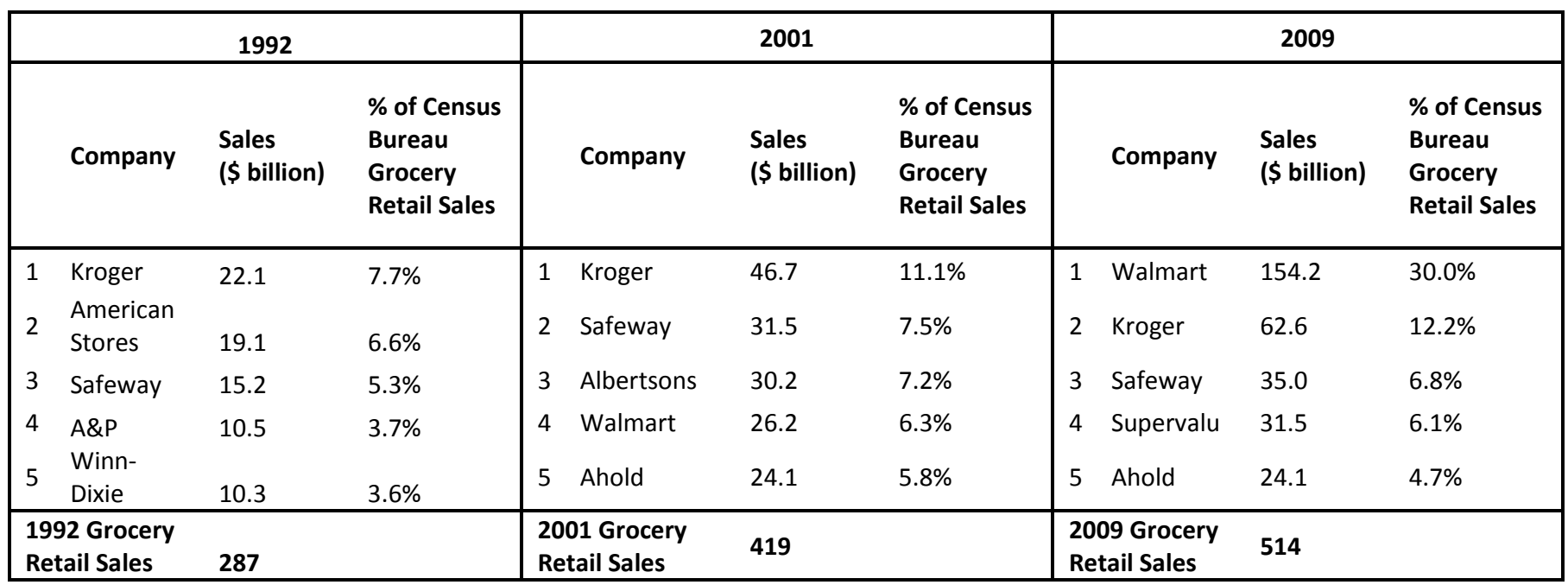

Source: adapted from Bank of America/Merrill Lynch (2011); Wrigley (2001a); US Census Bureau

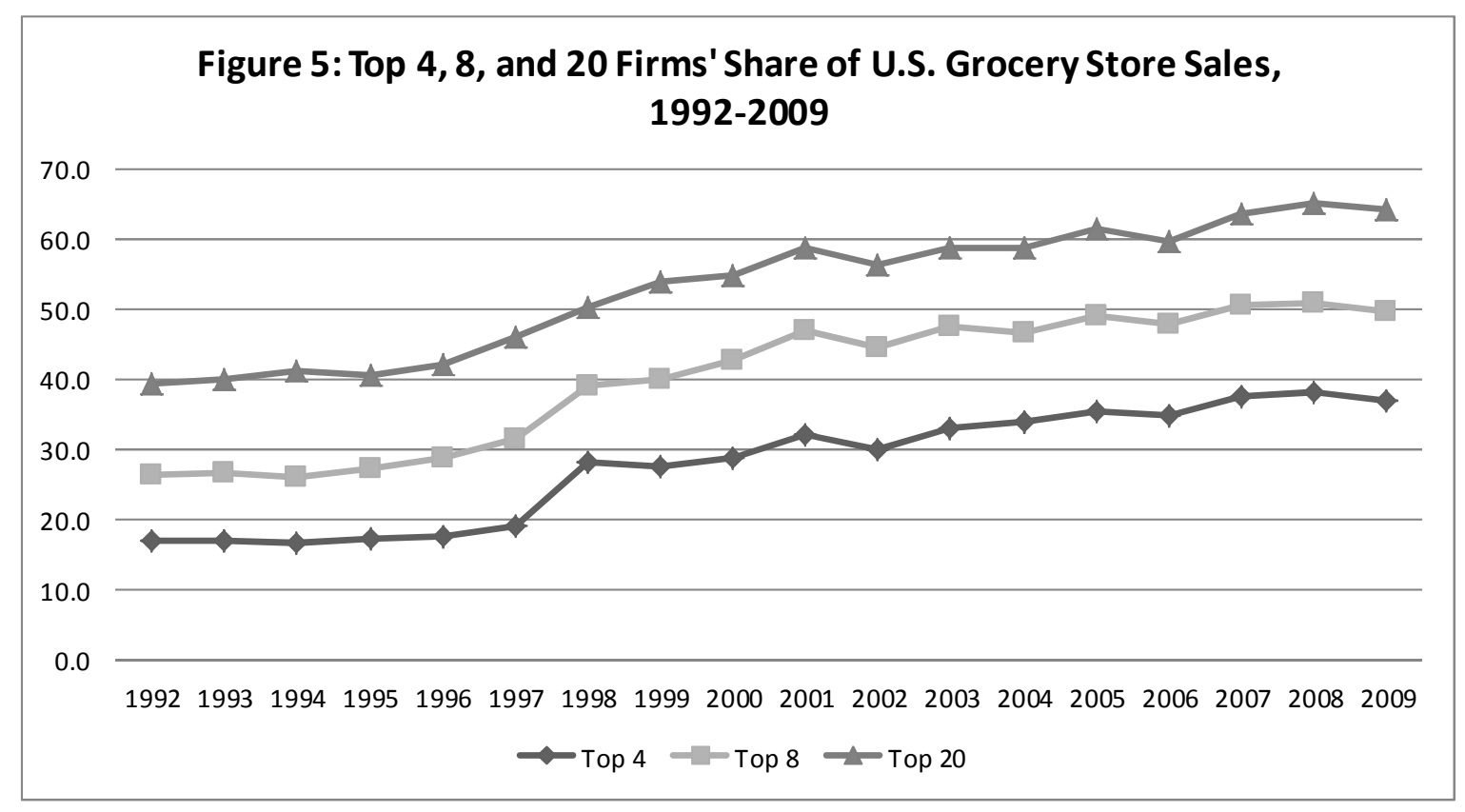

Source: USDA, ERS calculations using data from U.S. Census Bureau,

Monthly Retail Trade Survey, 1992-2009; and company annual reports.

\section{Implications for domestic retailer strategic position and international entrants}

The growing market power of the dominant food retailers has led the remaining food operators to reassess their own market positioning. Safeway has sought to differentiate itself as a higher end alternative to the discounters - in the process the retailer has dedicated high levels of capital expenditure to marketing and brand building. A key development for the retailer has been the development of the "Lifestyle" store format as a direct challenge to higher-end food operator, Whole Foods stores and features sushi and olive bars, internal store remodels and in-store Starbucks 
concessions (Wall Street Journal, 2007). Meanwhile, Ahold's remaining Stop \& Shop and GiantLandover retail chains underwent a price re-positioning ("Value Improvement Program") which was publicly acknowledged to negatively affect gross margin ${ }^{6}$ and introduced new branding, and store appearance. Meanwhile, between 2007-2010, the Giant Landover division pursued a three-year store remodelling programme (Ahold, 2007; 2008; 2010). Similarly Kroger has focused on improving price competitiveness, and also dedicated up to $20 \%$ of its capital expenditure to logistics and technology upgrading (Kroger, 2010).

For international retail entrants, the US food retail market has proven to be a difficult environment within which to develop a scalable business. While the trials of Dutch food operator, Ahold were discussed extensively earlier, UK food retailers have found US expansion problematic. At the time of Wrigley's late 1990s research, UK food retailer, Sainsbury's owned Shaw's which had taken a minority share in Giant (subsequently purchased by Ahold), acquired New England-based Star Markets and had also been the beneficiary of divested stores arising from the Stop \& Shop - Ahold merger in Connecticut. However, while the retailer had built scale, by the end of the $20^{\text {th }}$ Century, Wrigley (2000a, p 914-5) acknowledged that it 'found itself further marginalized from the pace of US food retail consolidation' and 'firmly within the third tier of US food retailers and was progressively losing touch with the leaders as the consolidation wave in the industry swept on'. Unsurprisingly, in 2004, J Sainsbury sold Shaw's to Albertsons for $\$ 2.48$ billion as its UK core market performance stuttered.

More recently, in 2007, UK food retailer Tesco entered the US west coast through the innovative organic development of a convenience supermarket format- the outcome of a lengthy customer research period in situ by the retailer's marketing and site research executives (Lowe and Wrigley, 2009; 2010). Emphasising convenient locations, quality food, as well as price, the stores aimed to occupy a differentiated market position compared to the large superstores and hypermarkets that proliferate throughout the sector. However, the market entry coincided with the 2007/08 financial crisis and subsequent economic downturn that especially affected California. Subsequently the firm's expansion stalled for a period in 2008, 25 stores have been mothballed and the business is not expected to break even until 2013-14 (Lowe et al., 2012). Although media speculation persists that Tesco may divest its current 185 store portfolio given the slower than anticipated returns and opportunity cost of capital (Felsted, 2012), the retailer suggests that many of the stores themselves

\footnotetext{
${ }^{6}$ In 2007, the retailer acknowledged that gross profit in its US operations decreased from $26.7 \%$ in 2006 to $25.9 \%$ in 2007 primarily due to price repositioning initiatives at Stop \& Shop/Giant-Landover (Ahold, 2007, p 16).
} 
are breaking-even so the likelihood of such action appears to have reduced. In contrast to these challenging cases, there are success stories relating to international entry and expansion in the US such as German discounter, Aldi which continues to grow given its well-defined low price, small format discount offer and also its differentiated, quirky Trader Joes speciality grocery store format (see Figure 3). In addition, Belgian retailer, Delhaize continues to perform robustly, principally through its Food Giant chain with stores concentrated in the south-east of the US.

\section{Implications for suppliers and labour}

The influence of Walmart's highly efficient store and logistics operations have been matched - where appropriate - by its centralised sourcing operations as its competitive impact has affected not only traditional food retailers but also non-food specialists such as electrical retailers. As research focused on buyer-driven global commodity chains has underlined, global sourcing networks, particularly stretching into East Asia, have obtained reliable, high volume supplies of quality, low cost goods that have proved attractive in the price sensitive end of the US market ${ }^{7}$ (Hamilton and Gereffi, 2009).

In common with many other developed retail markets, the increasing concentration of retailer power is progressively shifting the balance of power between retailers and manufacturers in the retailers' favour. The pressure especially from Walmart has led to a relentless search for scale and associated efficiencies throughout the value chain, thereby increasing pressure on suppliers. In the case of Walmart's sourcing, Mottner and Smith (2009) note that gross margins are significantly lower for Walmart suppliers compared to those dealing with other retailers, suggestive of pricing concessions and a dependency model of market power. Indeed, many suppliers that are large businesses in their own right are locked into a dependent relationship with Walmart with sometimes as much as 35-55\% of their business channelled to the retailer (Berg and Roberts, 2012). This is despite many of the suppliers concerned undergoing considerable increase in scale themselves over the past decade notably in the Fast Moving Consumer Goods (FMCG) sector with the landmark acquisition by Proctor and Gamble of Gillette for $\$ 55 \mathrm{bn}$ widely regarded partly as a strategic response to the purchasing scale enjoyed by leading retailers (Politi and Grant, 2005). In contrast, other suppliers such as American consumer-goods company, Sara Lee have divested businesses such as its Household and Body Care and Fresh Bakery operations which might have been regarded as peripheral to its focus.

\footnotetext{
${ }^{7}$ It is important not to over-emphasise the practical application of a homogenous global sourcing thesis. Berg and Roberts (2012), while noting the centralised sourcing that can occur for relatively standardised appliances such as entry level microwaves, emphasise that the heterogeneous nature of customer demand between countries and continents limits the extent to which global sourcing can realistically occur in, for example, apparel.
} 
Such strategies exhibit an emphasis on the core competencies of the firm (cf. Prahalad and Hamel, 1990) and free-up greater resources to dedicate to the role of lead suppliers as 'category captains' in their relationships with large retailers (see Gooner et al., 2011).

The imbalance of power is equally evident in the increasing supplier participation in retailer private label food product lines across the industry, which retail analysts, Planet Retail, forecast will increase at the Top 30 grocers by $40 \%$ to $\$ 209$ billion by 2014 , equating to $24.1 \%$ of the total grocery market (Chain Store Age 2010). The larger food retailers have increasingly pursued sophisticated private label strategies, first evident within the UK market with Tesco's "Value", "Own Label" and "Finest" offerings. For example, Kroger operates such a "Good, Better, Best" brand strategy via its "Value", "Banner Brand" and "Private Selection" labels. No doubt these initiatives have been partly facilitated by the economic downturn. At the end of 2011, Datamonitor's Product Launch Analytics estimated that store brands accounted for $31.4 \%$ of the 14,400 new food and beverage items introduced to the US in that year - double that in 2010 (Boyle, 2011).

The competitive cost pressure has been such that the established food retailers have challenged the power of unions with Vons (Safeway), Ralphs (Kroger) and Albertsons (at that time an independent firm) incurring a costly five-month strike in southern California in 2003-2004 as they compelled workers to accept benefit reductions, noting the competitive threat posed by the non-unionised Walmart (Birchall, 2005). A similar strike was averted most recently in September 2011 when, as the Los Angeles Times (2011) put it, 'Another strike would have severely damaged both sides'. The geography of the concentration of retail capital has progressively eroded the relative power of unions vis-à-vis retailers. The collective bargaining era where the unions could negotiate at a local level has become increasingly degraded in a concentrated market dominated by larger retail firms. That is to say, each local market area increasingly constitutes a lower proportion of the food retailers' revenues and therefore 'each local bargaining agreement now represents a smaller share of each company's operations, and union leverage is reduced proportionality' (Hurd, 2008, p 2). The pressures of having a unionised workforce in the face of a key competitor that does not (and therefore does not incur the additional costs associated with labour relations) remains. 


\section{Regulation and FTC Enforcement: The Case of Whole Foods - Wild Oats Markets}

Competitive strategy within food retailing has not only been focused on cost reduction and scalerelated efficiency realisation. Some operators have identified and leveraged a differentiated position by credibly locating themselves far from the price-focused competition. High-end food supermarket, Whole Foods Market has experienced significant market expansion in the past decade, tripling its store numbers between 1999 and 2011 to over 300, with particular emphasis in California as well as in the east and south-west of the US. This market growth was aided by the 2007 acquisition of Wild Oats Markets Inc., a natural and organic foods retailer for $\$ 565$ million, which, at the time of the proposed acquisition, operated 110 stores in 24 states and Canada. However, attaining regulatory permission for the consolidation was far from straightforward and deserves some analysis in the context of previous FTC rulings.

The 2000-2011 period did not see large-scale merger and acquisition activity in the food retail market and hence FTC intervention was far from the scale experienced in the 1990s - as Wrigley (2001b, $p$ 193) had forecast, any potential competition concerns would be strictly dealt with given the 'FTC's new stance on inadequate divestiture remedies and on the momentum of the acquiring firm'. The decline of the large-scale food retail consolidation was also attributable to the limited synergies commonly realised (with the notable exception of the Kroger-Fred Meyer transaction) and the more restricted finance available to fund such transactions. Instead, attention shifted to smaller, "cherry picking" acquisitions that could complement the acquirer's existing store geography, such as Kroger's acquisition of 20 Farmer Jack stores in the Detroit area in 2007 and its 2011 purchase of 17 stores in the Memphis, Tennessee market from St. Louis-based Schnuck Markets (Zwiebach, 2007; Supermarket News, 2011a).

The Whole Foods - Wild Oats transaction was notable in prompting a rapid response from competition authorities in a period of otherwise limited action. The principal issue was one of market definition: Whole Foods, the high-end food retailer - clearly considering the product market for its merchandise to be the broad food retail market - assumed a high level of competition in each of its respective local markets given the wide array of supermarket, superstore and hypermarket retailers that sold high-end organic produce in addition to their mainstream product lines. The retailer did not recognise a narrower, discrete market; one labelled "premium natural/organic supermarkets" (PNOS). 
Whole Foods consequently failed - in the context of the FTC's 2004 merger guidance to horizontal spatial overlap - to voluntarily divest stores in a fix-it-first type approach. In June 2007, a temporary restraining order and preliminary injunction was issued by the FTC that contradicted an initial positive finding of the US District Court for the District of Columbia, suggesting that the transaction violated Section 7 of the Clayton Act due to horizontal market overlap with its closest competitor:

In each of the markets in which they overlap, Whole Foods and Wild Oats are each other's closest substitute and compete in quality and prices, according to the Commission. After the merger, Whole Foods likely would be able to raise prices unilaterally, to the detriment of customers of premium natural and organic supermarkets (FTC, 2007).

Such interpretation of the product market had partial historic precedents in judgements within the US retail industry. Additional divestiture was ordered in American Stores' acquisition of Lucky Stores in 1988 when the State of California challenged the FTC's interpretation of the relevant product market to be broad and include groceries from a wide range of outlets (including mom-and-pop retail grocery stores, community grocery stores, and non-grocery outlets such as department stores and gas stations). Instead, the State of California successfully argued that the relevant product market was stores capable of offering a" one-stop shopping destination" - supermarkets defined as more than $10,000 \mathrm{sq} f t$. This was accepted and led to 161 stores being divested compared to the 31-37 that had previously been agreed with the FTC (Balto, 2001). Similarly, the proposed merger in 1997 between the first and second largest US office superstore chains; Staples and Office Depot, was effectively killed off when the FTC defined office supply superstore as a separate product market, independent of all other forms of retail (Werden, 2000). Such a view rested on econometric analysis suggesting that prices at Staples were higher in markets where office supply superstores faced little office superstore competition (see Baker and Pitofsky, 2007). However, as Shugart (1998) notes, had the market included sales of office products at independent, mail order and discount retailers, then the Staples and Office Depot's combined market share would have represented a mere $5 \%$.

Despite some precedents, the Whole Foods decision appeared an especially restrictive interpretation of a distinct product market given that organic and health foods could be purchased across a wide array of spatially proximate supermarkets, superstores, hypermarkets and supercenters, in addition to the specific "premium natural/organic supermarkets" (PNOS) category. A legal battle between the retailer, the FTC and the District Court was set in train when the District Court for the District of Columbia denied the FTC's request for a preliminary injunction related to the proposed merger. 
Having considered evidence from the retailers concerned and their claims regarding customers' cross shopping between their high end stores and conventional food supermarkets, the Court for the District of Columbia concluded that "...the FTC has not met its burden to prove that 'premium natural and organic supermarkets' is the relevant product market in this case for antitrust purposes" (cited in Farrell and Shapiro, 2010, p 5). In particular, the Court stated that:

[If] the relevant product market is, as the FTC alleges, a product market of "premium natural and organic supermarkets" consisting only of the two defendants and two other non-national firms, there can be little doubt that the acquisition of the second largest firm in the market by the largest firm in the market will tend to harm competition in that market. If, on the other hand, the defendants are merely differentiated firms operating within the larger relevant product market of "supermarkets," the proposed merger will not tend to harm competition. (cited in Farrell and Shapiro, 2010, p 5).

As Lambert (2008, p 25) put it, the District Court viewed "premium natural/organic supermarkets" (PNOS) to actually be part of a wider supermarket sector with implied cross-shopping by consumers between them:

the district court concluded that Whole Foods and Wild Oats are not insulated from significant competition from conventional grocery store chains. Instead, they compete with conventional supermarkets and conventional supermarkets compete with them. When those other supermarkets are considered part of the relevant market, it becomes clear that the merger of two relatively small players in the much larger overall market would not give the combined firm the power to raise price and/or cut back on services, to the detriment of consumers. The district court therefore properly denied the FTC's motion for preliminary injunction.

The FTC appealed this decision and won a remand. After lengthy investigation (Pettit, 2009), the antitrust battle was finally settled in March 2009. Whole Foods agreed to divest itself of 31 Wild Oats stores across 12 states - a number that included 19 stores that were already closed along with a single trading Whole Foods store. Whole Foods also agreed to relinquish the rights to the Wild Oats brand, which could be sold to a potential competitor (FTC, 2009). Of course this hardly represented divestiture centred on the 'ongoing businesses' that were deemed so important by the FTC in their assessment of effective divestitures a decade earlier (cf. FTC, 1999). Such a judgement was unsurprisingly widely regarded as a qualified victory for the retailer against the FTC (Reuters, 2009) not only did the enforced divestment include already unwanted units, the FTC's insistence that the Wild Oats brand was available for purchase did not guarantee that such a competitor would emerge ${ }^{8}$.

\footnotetext{
${ }^{8}$ In 2010 Luberski Inc., a supplier of dairy products, won the right to the Wild Oats intellectual property.
} 
Beyond the immediate implications for Whole Foods, it remained unclear whether the reductive market definition had set a precedent for the "premium natural/organic supermarkets" (PNOS) product market (Fricke, 2010). As the Wall Street Journal suggested, 'it remains questionable whether it will have much impact on competition in the market for organic and natural foods - the original basis of the suit' (Martin, 2009). Indeed, the question posed by Balto (2001, p 41) remains apposite, while retail formats change and develop, 'At what point do they become part of the relevant product market?' What the episode does underline however is that there certainly has been no return to the laissez-faire approach that typified the FTC's actions during the early 1990s when the "hands-off" fixit-first approach to merger resolution was increasingly regarded as ineffective and played a major facilitating role in re-making the economic geography of the US food market. Indeed, the Department of Justice's most recent Policy Guide to Merger Remedies (2011) has suggested that harsher resolutions may be on the horizon with increased scope for behavioural remedies to anti-competitive merger outcomes alongside the structural resolutions such as divestiture that are well established (Kwoka and Moss, 2011) - however, quite how behavioural remedies could be implemented into retail transactions remains unclear.

Beyond the immediate concerns with this specific instance of competition policy enforcement, it is clear that despite the FTC adopting a more responsive stance to rulings concerning retail horizontal market overlap in merger and acquisition activity, it has failed to prevent the market concentration within a food retail sector where the top two retailers are responsible for in excess of $42 \%$ of sales (as detailed in Table 5). In common with the situation in the UK, competition policy has been curiously blind to concentration that occurs as a result of organic development ${ }^{9}$. Furthermore, one could speculate that the FTC has failed to consider the implications of increasing market power leveraged by retailers for suppliers and manufacturers. Surprisingly, in 2005 the former FTC Chairman, Timothy Muris asserted an extremely restrictive view of market power:

Market power, of course, exists only at the horizontal level. Only actual and potential rivals can constrain those who seek to exercise market power (Muris, 2005, p 841; see also Steiner, 2011).

\footnotetext{
${ }^{9}$ As the UK's Competition Commission (2008, p 183) acknowledged, the blend of competition policy and land use planning has been ineffective at restricting continued increases as 'the planning regime....as it currently exists ... would not be sufficient to prevent the emergence of highly-concentrated local markets or the strengthening of strong local market positions held by particular retailers'.
} 
Finally, given that market definition within retail competition rulings remain a central concern, it will be intriguing to observe how the increasing penetration of online sales will affect the identification and delineation of markets in horizontal mergers. It is unlikely to be as easy to identify and isolate discrete product markets. As An et al. (2010, p 2) note, 'One complication is the question of the relevant number of competitors, including whether online and traditional retailers selling similar products are in the same product market'. Within product markets where online claims a high proportion of sales, it may be increasingly difficult to legitimately assert that online and offline markets are separate anti-trust markets.

\section{CONCLUSIONS: REFLECTING ON THE THEMATIC LEGACIES FOR ECONOMIC GEOGRAPHY}

The flow of outputs related to Wrigley's analysis of the changing economic geography of the US food retail market have provided clear insights to a specific region's economic geography, but more widely developed under-researched themes within the discipline that have since become key areas of focus in the decade since. To conclude, I briefly identify these themes and set them in their contemporary context.

\section{Linking firm finance and the geography of the retail organisation}

Wrigley's linking of the role of firm finance and capital structure in partly determining the economic geography of retailing have important implications for studies specifically focused on understanding strategy at the firm and industry level (O'Neill, 2001; Pollard, 2003), the relationship with investors (Wray, 2012; Wrigley and Currah, 2003) and also funding strategy in the context of wider financial geography scholarship (Dixon, 2011). Subsequent work focused on retail TNCs has underlined how the ability to raise finance is, in turn, linked within the institutional context and the specific varieties of capitalism within which it is located (Okeahalam and Wood, 2009; cf. Clark and Wójcik, 2007; Whitley, 2001). Meanwhile, other research has explored how divestiture driven by constrained capital can itself be strategic in nature if implemented intelligently (Palmer and Quinn, 2007). More widely, Wrigley's focus on the implications of constrained capital structure and spatial rationalisation has identified the potential effects of decreased retail investment within some retail catchments. In the context of debt burdens from the LBO period, he noted the effects for US food retailing:

An important spatial consequence of attempting to spread such limited capital expenditure over large store networks was that certain markets in the United States became deprived of investment and suffered deterioration in their store base (Wrigley, 1999b, p 202). 
These concerns have led to recent scholarship emphasising a social justice concern with 'food deserts'. In particular, research that has explored the 'before and after' effects of new store development on consumer diet (e.g. Cummins et al., 2005; Wrigley, 2002c; Wrigley et al., 2003) have influenced the highest levels of government both in the UK and US (e.g. United States Department of Agriculture, 2009), emphasising a concern for policy relevant economic geography research (Wrigley, 2011). More work needs to be undertaken concerning the geographies of food retail provision: in surveying the research on this issue, Dawson et al. (2008, p 894) note that all too often 'survey results appear contradictory, anecdotal or [are] misinterpreted'.

\section{The role of the regulatory state and corporate response}

Wrigley's research placed considerable importance on the role of market rules in affecting the direction of investment and ultimately spatial outcomes. While such issues had previously been discussed within economic geography to some extent (cf. Christopherson, 1993), the detailed tracing of their dynamic change over time, the narratives flowing between regulator and firm, and the implications that this has for corporate strategy and investment has contributed to a rich understanding within the discipline. Such themes have been evident in subsequent work that has analysed the implications for subsequent consolidation activity within food retailing. In a UK context, Wrigley (2002b) noted that the new market entrant (at the time), Walmart would have limited merger and acquisition expansion opportunities due to competition regulation. Such forecasts proved to be correct in 2004 when struggling UK food retailer, Safeway, was acquired by fourth-placed operator, Morrisons, largely due to the local geographies of retailer store portfolios making regulatory intervention inevitable if an outright purchase was attempted by one of larger players (see Poole et al., 2002a; cf. Poole et al., 2002b; 2006).

In addition, work has developed that has better conceptualised the implications of market regulation for international retail expansion, particularly in terms of host market governance in managing the politically charged impact of foreign entrants on indigenous operators (Franz, 2010; Mutebi, 2007; Reardon and Hopkins, 2006). Meanwhile, land use planning within certain domestic markets has been related to adaptive retailer responses and corporate coping strategies (Guy and Bennison, 2007; Wood et al., 2006; 2010) - something increasingly necessary in understanding the implications of changing rules. Indeed, when contrasting the regulatory frameworks in operation between the UK and US in the mid-1990s, Wrigley (1997a) noted the lack of attention to local markets as: 
Essentially, the United Kingdom has not operated a policy of local competition regulation aimed at mitigating the monopolistic potential of such mergers and strengthening the competitive process within local markets. UK competition law and regulatory practice has, in effect, been curiously blind to geography (Wrigley, 1997a, p 1151).

Inevitably such oversights were subsequently challenged and the outcome of a Competition Commission Inquiry was a proposed Local Competition Test that, when implemented, will require a thorough spatial analysis from geographers (Hughes et al., 2009). Such practical application of research underlines the importance of economic geography retaining a concern with issues of market regulation and spatial outcomes, not least given the politically charged nature of retail power and food provision that have clear implications for economic growth and arguably social justice.

\section{Acknowledgements}

I am extremely grateful to Simon Bills of McKinsey \& Co and Neil Wrigley for the benefit of discussions relating to the US food retail sector and feedback on earlier drafts. In addition, I appreciate the assistance of David E. Pettit of Latham \& Watkins LLP and Jessica M.Fricke of Kozacky \& Weitzel P.C. for information relating to the Whole Foods-Wild Oats merger. Finally, I am thankful to Bryan Roberts of Kantar Retail for answering queries concerning US suppliers and retail real estate. As always, all errors and omissions remain my own.

\section{References}

Ahold (2006 - 2010) Ahold Annual Reports (2006 - 2010 inclusive)

An, Y., Baye, M. R., Hu, Y., Morgan, J., Shum, M. (2010) Horizontal Mergers of Online Firms: Structural Estimation and Competitive Effects, The Johns Hopkins University, Department of Economics, Working Paper No. 2010-17.

Baer, W.J. (1996) Reflections on 20 years of merger enforcement under the Hart-Scott-Rodino Act. Prepared remarks of William J Baer, Director, Federal Trade Commission before The Conference Board, Washington DC, 29 October, and The 35th Annual Corporate Counsel Institute, Corporate Law Center, San Francisco, 31 October.

Baer, W. J., Redcay, R. C. (2001) Solving competition problems in merger control: the requirements for an effective divestiture remedy, The George Washington Law Review, 69: 1701-1712.

Baker, G. Smith, G. (1998) The New Financial Capitalists: Kohlberg Kravis Roberts and the Creation of Corporate Value, Cambridge University Press, Cambridge.

Baker, J., Pitofsky, R. (2007) Turning point in merger enforcement: Federal Trade Commission v. Staples. In E. Fox and D. Crane (eds) Antitrust Stories, Foundation Press, pp. 311-330

Balto, D. A. (2001) Supermarket merger enforcement, Journal of Public Policy \& Marketing, 20: 38-50

Bank of America/Merrill Lynch (2011) 2011 Year ahead: A fork in the road for food retailing stocks. BofA Merrill Lynch Equities, Food Retailing, 15 February 2011.

Berg, N. and Roberts, B. R. (2012) Walmart: Key Insights and Practical Lessons from the World's Largest Retailer, Kogan Page Ltd, London, England. 
Birchall, J. (2005) Kroger meets Wal-Mart head-on, Financial Times, December 18, 2005

Birchall, J. (2006) Supervalu enters the big league, Financial Times, January 24, 2006

Birmingham Business Journal (2004) Lone Star Funds agrees to buy Bruno's from Ahold, Birmingham Business Journal, December 23, 2004

Boyle, M. (2011) Business report: Grocers boost private labels to reach deal hunters, Bloomberg BusinessWeek, November 27, 2011.

Cao, L. (2011) Dynamic capabilities in a turbulent market environment: empirical evidence from international retailers in China, Journal of Strategic Marketing, 19: 455-469.

Carden, A., Courtemanche, C., Meiners, J., (2009). Does Wal-Mart reduce social capital? Public Choice $138(1 / 2), 109-136$.

Chain Store Age (2010) Report: Top 30 North American grocers to generate \$209B in private-label sales by 2014, Chain Store Age, September 142010.

Chevalier, J. A. (1995) Capital structure and product-market competition: empirical evidence from the supermarket industry, American Economic Review, 85: 415-435.

Christopherson, S. (1993) Market rules and territorial outcomes: the case of the United States. International Journal of Urban and Regional Research, 17: 274-288.

Clark, G. L. (1992a) Remaking the map of corporate capitalism: the arbitrage economy of the 1990s. Environment and Planning A, 21: 997-1000.

Clark, G. L. (1992b) 'Real' regulation: the administrative state. Environment and Planning A, 24: 615627.

Clark, G. L., Wojcik, D., Bauer, R. (2006) 'Geographically dispersed ownership and inter-market stock price arbitrage - Ahold's crisis of corporate governance and its implications for global standards', Journal of Economic Geography, 6: 303-22

Clark, G., and Wrigley, N. (1997) The spatial configuration of the firm and the management of sunk costs, Economic Geography, 73: 285-301.

Coe, N. (2004) The internationalisation/globalisation of retailing: towards an economic-geographical research agenda. Environment and Planning A, 36: 1571-1594.

Coe, N., Wrigley, N. (2009) Introduction. In Coe, N. and Wrigley, N. (eds). The Globalization of Retailing, Edward Elgar, Cheltenham, UK, pp. xiii-xxxviii.

Competition Commission (2008) The Supply of Groceries in the UK Market Investigation. Final Report. 30 April 2008. Accessed at http://webarchive.nationalarchives.gov.uk/+/http://www.competitioncommission.org.uk/rep pub/reports/2008/fulltext/538.pdf

Cotterill, R.W. (1991) Food retailing: mergers, leveraged buyouts, and performance. Food Marketing Policy Center Research Report No. 14, Department of Agricultural and Resource Economics, The University of Connecticut.

Cummins, S., Petticrew, M., Higgins, C., Findlay, A., Sparks, L. (2005) Large scale food retailing as an intervention for diet and health: quasi-experimental evaluation of a natural experiment. Journal of Epidemiology and Community Health 59: 1035-1040.

Dawson, J., Marshall, D., Taylor M., Cummins, S., Sparks, L., Anderson, A. (2008) Accessing healthy food: availability and price of a healthy food basket in Scotland. Journal of Marketing Management 24: 893-913. 
Denis, D. J. (1994) Organizational form and the consequences of highly leveraged transactions: Kroger's recapitalization and Safeway's LBO. Journal of Financial Economics 36: 193-224.

Denis, D. J. (1995) The benefits of high leverage: lessons from Kroger's leveraged recap and Safeway's LBO. Journal of Applied Corporate Finance 7: 38-52.

Dixon, A. D. (2011) Variegated capitalism and the geography of finance: Towards a common agenda, Progress in Human Geography, 35: 193-210.

Dunn, R. Reader, S. and Wrigley, N. (1983) An investigation of the assumptions of the NBD model as applied to purchasing at individual stores, Applied Statistics (J of the Royal Statistical Society, Series C), 32: 24959

Farrell, J. and Shapiro, C. (2010) Antitrust evaluation of horizontal mergers: an economic alternative to market definition, The B.E. Journal of Theoretical Economics, 10 (1) (Policies perspectives), Article 9. Available at: http://www.bepress.com/bejte/vol10/iss1/art9

Felsted, A. (2012) Tesco to shut 12 more Fresh \& Easy stores, Financial Times, January 10, 2012.

FTC (Federal Trade Commission) (1999) A Study of the Commission's Divestiture Process. Prepared by the Staff of the Bureau of Competition of the Federal Trade Commission. Available for download at http://www.apeccp.org.tw/doc/USA/Policy/usapol02.pdf

FTC (2007) News Release: FTC Seeks to Block Whole Foods Market's Acquisition of Wild Oats Markets. June 5, 2007.

FTC (2009) News Release: FTC Consent Order Settles Charges that Whole Foods' Acquisition of Rival Wild Oats was Anticompetitive, 6 March 2009.

FTC (2010) News Release: FTC Approves Whole Foods Market's Divestiture of Three Stores and Wild Oats Intellectual Property, Denies Sale of Wild Oats Intellectual Property to Topco Associates, 18 June 2010.

Franz, M. (2010) The role of resistance in a retail production network: Protests against supermarkets in India. Singapore Journal of Tropical Geography, 31: 317-329.

Fricke, J. (2010) FTC V Whole Foods Market: a new FTC preliminary injunction standard? DePaul Business \& Commercial Law Journal 8: 173-195.

Goetz, S.J., Rupasingha, A. (2006) Wal-Mart and social capital. American Journal of Agricultural Economics 88 (5), 1304-1310.

Gooner, R.A., Morgan, N.A. and Perreault, W.D. (2011) Is retail category management worth the effort (and does a category captain help or hinder)? Journal of Marketing 75: 18-33.

Grant, J. (2005) Retailer forced to file for Chapter 11, Financial Times, February 23, 2005

Gray, A., Broadbent, J.,Lavender, M. (2009) Editorial: PMM, the impact of research on practice, and the emerging Research Excellence Framework. Public Money \& Management, 29: 139-140.

Guy, C., Bennison, D. (2007) Planning guidance and large-store development in the United Kingdom: the search for 'flexibility'. Environment and Planning A, 39: 945-964.

Halebsky, S (2004) Superstores and the politics of retail development, City and Community, 3: 115-34.

Hamilton G., Gereffi G. (2009) Global commodity chains, market makers, and the rise of demandresponsive economies. In: Bair J (ed) Frontiers of Commodity Chain Research. Palo Alto: Stanford University Press, 136-161. 
Hughes, A. (1999) Constructing competitive spaces: on the corporate practice of British retailer supplier relationships. Environment and Planning A, 31: 819-839.

Hughes, R., Hallsworth, A., Clarke, G. (2009) Testing the effectiveness of the proposed UK 'competition test', The Service Industries Journal, 29: 569-90

Hurd, R.W. (2008) Collective bargaining in the era of grocery industry restructuring, Articles and Chapters. Paper 284. Accessed at http://digitalcommons.ilr.cornell.edu/articles/284

IGD (2011) Walmart: Driving the Productivity Loop Harder, December 2011.

Irwin, E. G., Clark, J (2006) The Local Costs and Benefits of Wal-Mart, Department of Agriculture and Development Economics, Ohio State University.

Jensen, M. C. (1986) Agency costs of free cash flow, corporate finance, and takeovers, American Economic Review, 76: 323-329.

Jensen, M. C. (1988) The takeover controversy: analysis and evidence. In J. Coffee, L. Lowenstein, S. Rose-Ackerman (eds.) (1988) Knights, Raiders and Targets: Analysis and Evidence, Oxford University Press, Oxford, pp314-354.

Jensen, M. C. (1989a) The eclipse of the public corporation, Harvard Business Review, 67 (5): 61-74.

Jensen, M. C. (1989b) Active investors, LBOs and the privatisation of bankruptcy, Journal of Applied Corporate Finance, 2 (1), 35-44.

Johnston, R. (2008) On structuring subjective judgements: originality, significance and rigour in RAE2008. Higher Education Quarterly, 62, 120-147.

Jopson, B. (2011) Bi-Lo to take Winn-Dixie private in $\$ 560 \mathrm{~m}$ deal, Financial Times, $19^{\text {th }}$ December 2011.

Kroger (2010) The Kroger Co. 2010 Fact Book.

Kaufman, P. (2000) Grocery retailers demonstrate urge to merge, Food Review: The Magazine for Food Economics, 23 (2): 29-342.

Kwoka, J., Moss, D. (2011) Behavioral Merger Remedies: Evaluation and Implications for Antitrust Enforcement, American Antitrust Institute Working Paper, November 14, 2011.

Lambert, T. (2008) Four lessons from the Whole Foods case, Regulation, Spring 2008, pp. 22-29.

Los Angeles Times (2011) Supermarket chains, union avert strike, Los Angeles Times, 22 September 2011, p 4.

Lowe, M., Wrigley, N. (2009) Innovation in market entry: Tesco in the USA. International Review of Retail, Distribution \& Consumer Research, 19: 331-347.

Lowe, M., Wrigley, N. (2010) The 'continuously morphing' retail TNC during market entry: interpreting Tesco's expansion into the USA, Economic Geography, 86: 381-408.

Lowe, M., George, G., Alexy O. (2012) Organizational identity and capability development in internationalization: transference, splicing and enhanced imitation in Tesco's US market entry. Journal of Economic Geography. In press - pre-print availabile: doi:10.1093/jeg/lbs016

Martens, B. (2008) The effect of entry by Wal-Mart supercenters on retail grocery concentration, Journal of Food Distribution Research, 39(3): 13-28.

Martin, T. (2009) Whole Foods to Sell 31 Stores in FTC Deal, Wall Street Journal, March 72009.

Morgan Stanley (2007) Press Release: Morgan Stanley Private Equity to Acquire Tops Markets, October 11 2007. Accessed at http://www.morganstanley.com/about/press/articles/5624.html 
Mottner, S., Smith, S. (2009) Wal-Mart: Supplier performance and market power, Journal of Business Research, 62: 535-41

Muris, T. (2005) More than law enforcement: the FTC's many tools - a conversation with Tim Muris and Bob Pitofsky, Antitrust Law Journal, 72: 773-860.

Mutebi, A. M. (2007) Regulatory responses to large-format transnational retail in south-east Asian cities. Urban Studies, 44: 357-379.

NACS (2012) NACS Industry Resources. Accessed at http://www.nacsonline.com/NACS/News/FactSheets/Pages/default.aspx

Opler, T., Titman, S. (1993) The determinants of leveraged buyout activity: free cash flow vs financial distress costs, Journal of Finance, 48: 1985-1999.

O'Neill, P. (2001) Financial narratives of the modern corporation, Journal of Economic Geography, 1: 181-199.

Palmer, M., Quinn, B. (2007) The nature of international retail divestment: Insights from Ahold. International Marketing Review 24: 26-45.

Paruchuri, S., Baum, J.A.C., Potere D. (2009) The Wal-Mart effect: Wave of destruction or creative destruction? Economic Geography 85: 209-236.

Pettit, D. (2009) Submarkets and supermarkets: FTC v. Whole Foods Market and the resurrection of Brown Shoe, George Mason Law Review, 16: 971-1009.

Politi, J., Grant, J. (2005) P\&G set to buy Gillette for \$57bn, Financial Times, January 29, 2005.

Pollard, J. S. (2003) Small firm finance and economic geography, Journal of Economic Geography, 3(4), 429-452.

Poole, R., Clarke, G., Clarke, D. (2002a) Grocery retailers and regional monopolies. Regional Studies, 36: 643-659.

Poole, R., Clarke, G., Clarke, D. (2002b) Growth, concentration and regulation in European food retailing. European Urban and Regional Studies, 9: 167-186.

Poole, R., Clarke, G., Clarke, D. (2006) Competition and saturation in West European grocery retailing. Environment and Planning A, 38: 2129-2156.

Pitofsky, R. (2000) The Nature and Limits of Restructuring in Merger Review. Cutting Edge Antitrust Conference, Law Seminars International, February 17, 2000, Empire Hotel, New York, N.Y. Available at http://www.ftc.gov/speeches/pitofsky/restruct.shtm

Prahalad, C.K., Hamel, G. (1990) The core competence of the corporation. Harvard Business Review 68 (3): 79-91.

Reardon, T., Hopkins, R. (2006) The supermarket revolution in developing countries: Policies to address emerging tensions among supermarkets, suppliers and traditional retailers. The European Journal of Development Research, 18: 522-545.

Reuters (2009) Whole Foods, FTC settle on Wild Oats merger. March 6 2009. Accessed at http://www.reuters.com/article/2009/03/06/us-wholefoods-ftc-idUSTRE5253AL20090306

Reuters (2012) Supermarket chain A\&P emerges from bankruptcy, March 132012 http://uk.reuters.com/article/2012/03/13/ap-bankruptcyidUKL2E8EDNXG20120313?rpc=401\&feedType=RSS\&feedName=governmentFilingsNews . 
Schwartz, R. A.,Lyson, T. A. (2007) Retail relations: an interlocking directorate analysis of food retailing corporations in the United States, Agriculture and Human Values, 24: 489-98

Shellock, D., Yuk, P. (2004) Ahold climbs on sale of US units, Financial Times, December 24, 2004.

Shugart W. (1998) The government's war on mergers: the fatal conceit of antitrust policy' Policy Analysis No. 323 Washington DC: Cato Institute October 221998

Smith, G. (2004) Ahold sells US businesses for \$660m, Financial Times, December 23, 2004.

Steiner, R. (2011) How Interactions between Vertical And Horizontal Competition Determine Welfare Outcomes in Consumer Goods Industries. Lecture at University of Oxford Centre for Competition Law and Policy, June 2, 2011. Copy available from author.

Supermarket News (2011a) Kroger buys Memphis Schnucks stores, Supermarket News, September. 2, 2011

Supermarket News (2011b) Data points, Supermarket News, February 72011.

Swinnen, J.F.M., Vandeplas, A. (2010) Market power and rents in global supply chains, Agricultural Economics, 41: 109-120.

Tedlow, R. S. (1996) New and Improved. The Story of Mass Marketing in America, Boston, MA: Harvard Business School Press.

Tse, T. and Williams, K. (2007) Royal Ahold Sells U.S. Foodservice to Private-Equity Firms, The Washington Post, Thursday, May 3, 2007.

United States Department of Agriculture (USDA) (2009) Access to Affordable and Nutritious Food: Measuring and Understanding Food Deserts and Their Consequences. Report to Congress, Economic Research Service, June 2009.

Wall Street Journal (2007) Not copying Wal-Mart pays off for grocers, Wall Street Journal, June 6, p

Werden G. (2000) Market delineation under the merger guidelines: monopoly cases and alternative approaches, Review of Industrial Organization,16: 211-218.

Whitley R (2001) How and why are international firms different? The consequences of cross-border managerial coordination for firm characteristics and behaviour, In Morgan G, Kristensen PH, Whitley R. (eds.) The Multinational Firm: Organizing Across Institutional and National Divides (Oxford University Press, Oxford), pp 27-68.

Winn-Dixie (2006) Press Release: Winn-Dixie Emerges from Chapter 11. November 21, 2006.

Wood, S. (2001) Regulatory constrained portfolio restructuring: the US department store industry in the 1990s, Environment and Planning A, 33: 1279

Wood, S. (2002a) The limits to portfolio restructuring: lessons from regional consolidation in the US department store industry, Regional Studies, 36: 515 - 29

Wood, S. (2002b) Organisational restructuring, knowledge and spatial scale: the case of the US department store industry. Tijdschrift voor economische en sociale geografie, 93: 8-33.

Wood, S., Lowe, M. and Wrigley, N. (2006) Life after PPG6: recent UK food retailer responses to planning regulation tightening. International Review of Retail, Distribution \& Consumer Research, 16: $23-41$.

Wood, S., Lowe, M. and Wrigley, N. (2010) Conceptualising innovative customer-facing responses to planning regulation: the UK food retailers, The Service Industries Journal, 30: 1967-90 
Wood, S., Reynolds, J. (2011) The intrafirm context of retail expansion planning, Environment and Planning A, 43: 2468-2491.

Wood, S., Reynolds, J. (2012) Managing communities and managing knowledge: strategic decision making and store network investment within retail multinationals, Journal of Economic Geography, 12: 539-565.

Wray, F. (2012) Rethinking the venture capital industry: relational geographies and impacts of venture capitalists in two UK regions, Journal of Economic Geography, 12: 297-319.

Wrigley, N. (1988) Store Choice, Store Location and Market Analysis Andover, UK: Routledge.

Wrigley, N. (1991) Is the golden-age of British grocery retailing at a watershed?, Environment and Planning A, 23: 1537-44

Wrigley, N. (1992) Antitrust regulation and the restructuring of grocery retailing in Britain and the USA, Environment and Planning A, 24: 727-49

Wrigley, N. (1993) Abuses of market power: further reflections on UK food retailing and the regulatory state, Environment and Planning A, 25: 1545-52

Wrigley, N. (1996) Sunk costs and corporate restructuring: British food retailing and the property crisis, in Retailing, Consumption and Capital: Towards the New Retail Geography eds. N. Wrigley and M. Lowe (Harlow: Addison-Wesley Longman)

Wrigley, N. (1997a) Foreign retail capital on the battlefields of Connecticut: Competition regulation at the local scale and its implications, Environment and Planning A, 29: 1141-52

Wrigley, N. (1997b) 'Exporting the British model of food retailing to the US: implications for the EU-US food systems convergence debate', Agribusiness, 13: 137-52

Wrigley, N. (1997c) British food retail capital in the USA - Part 1: Sainsbury and the Shaw's experience, British Food Journal, 99: 412-26

Wrigley, N. (1997d) British food retail capital in the USA - Part 2: Giant prospects? International Journal of Retail \& Distribution Management, 25: 48-58

Wrigley, N. (1997e) British food retail capital in the USA: preface and update, British Food Journal, 99 : 409-11

Wrigley, N. (1998a) Understanding store development programmes in post-property-crisis UK food retailing, Environment and Planning A, 30: 15-35

Wrigley, N. (1998b) European retail giants and the post-LBO reconfiguration of US food retailing, The International Review of Retail, Distribution and Consumer Research, 8: 127-46

Wrigley, N. (1999a) Market rules and spatial outcomes: Insights from the corporate restructuring of US food retailing, Geographical Analysis, 31: 288-309

Wrigley, N. (1999b) Corporate finance, leveraged restructuring and the economic landscape: the LBO wave in US food retailing, in Money and the space economy, ed. R. Martin (Chichester: Wiley)

Wrigley, N. (2000a) Strategic market behaviour in the internationalization of food retailing, European Journal of Marketing, 34: 891

Wrigley, N. (2000b) The globalization of retail capital: themes for economic geography, in The Oxford Handbook of Economic Geography, eds. G. L. Clark, M. P. Feldman and M. S. Gertler: New York and Oxford: Oxford University Press) 
Wrigley, N. (2001a) The consolidation wave in U.S. food retailing: a European perspective, Agribusiness, 17: 489-513

Wrigley, N. (2001b) Local spatial monopoly and competition regulation: reflections on recent UK and US rulings, Environment and Planning A, 33: 189-94

Wrigley, N. (2002a) Transforming the corporate landscape of US food retailing: market power, financial re-engineering and regulation, Tijdschrift voor economische en sociale geografie, 93: 6282

Wrigley, N. (2002b) The landscape of pan-European food retail consolidation, International Journal of Retail \& Distribution Management, 30, 81-91

Wrigley, N. (2002c) Food deserts' in British cities: policy context and research priorities, Urban Studies, 39: 2029-2040.

Wrigley, N (2010) The shifting geographies of UK retailing, in Coe, N.M and Jones, A (eds) The Economic Geography of the UK. London: Sage

Wrigley, N. (2011) Towards a Policy Engaged Retail Geography: Reflections from My Evolving Vision of the Subject, Keynote Paper Prepared for XXV Anniversary of El Colegio Mexiquense AC, September 2011

Wrigley N, Branson J, Murdock A., Clarke, G. (2009) Extending the Competition Commission's findings on entry and exit of small stores in British high streets: implications for competition and planning policy. Environment and Planning A 41: 2063-2085.

Wrigley, N., Coe, N., Currah, A. (2005) Globalizing retail: conceptualizing the distribution-based transnational corporation (TNC). Progress in Human Geography, 29: 437-457.

Wrigley, N., Currah, A. (2003) The stresses of retail internationalization: lessons from Royal Ahold's experience in Latin America, International Review of Retail, Distribution \& Consumer Research, 13: 221-43

Wrigley, N., Dunn, R. (1984) Stochastic panel-data models of urban shopping behaviour, 1: purchasing at individual stores in a single city. Environment and Planning A, 16: 629-650

Wrigley, N., Lowe, M. (1996) Retailing, Consumption and Capital: Towards the New Retail Geography Harlow: Addison-Wesley Longman

Wrigley, N., Warm, D., and Margetts, B. (2003) Deprivation, diet, and food-retail access: findings from the Leeds 'food deserts' study, Environment and Planning A, 35: 151-188.

Zwiebach, E. (2007) Whither consolidation? Supermarket News; $10^{\text {th }}$ September, 55 (37): 20-31. 